\title{
Changing the home literacy environment through participation in family literacy programmes
}

\section{Introduction}

This paper is based on a large mixed-methods study that investigated the impact of school-based family literacy programmes on young children's progress in reading and writing, and the influence family literacy provision has on the home literacy environment, which is the specific focus of this paper. The fieldwork took place in England between September 2013 and December 2014 and involved 27 school-based programmes for Year 1 and Year 2 pupils (aged between 5 and 7-years-old), and their parents [1].

The study builds on previous research and serves to confirm how family literacy can improve reading skills, enrich family relations, increase parental empowerment, and enhance home-school partnerships (e.g. BIS, 2014; Brooks et al., 1996, Brooks et al., 1997; Carpentieri et al., 2011; NALA, 2010; NIACE, 2013; See and Gorard, 2015; van Steensel et al., 2011).

Although many studies (in the UK and internationally) have looked at the impact of family literacy programmes on a variety of outcomes, several areas remain unexplored or provide a source of conflicting evidence. This paper sets out to address three gaps in the evidence. Firstly, and the main focus of this paper, although existing literature confirms the vital role of the family dimension in the literacy learning of young children and parents, research has very little to tell us 
about how, if at all, participation in programmes changes family's literacy attitudes, beliefs and practices; further there is almost no research on how parents translate and implement the messages they have been taught in family literacy programmes into the home, and how this may change the home literacy environment. Secondly, the majority of evaluations of family literacy have focused on quantifiable outcomes on children's emergent literacy progress in terms of attainment; qualitative research on participants' views and experiences (both children's and parents'), and the so-called 'softer' outcomes (e.g. Hodge, 2006; Nichols et al., 2009), have generally received less attention. Thirdly, there are very few methodologically sound empirical studies specifically investigating these issues in England, which leads to questions about the transferability and the validity of applying such evidence from different socio-cultural and political contexts.

The paper begins by reviewing previous research about family literacy, discusses the importance of the home literacy environment and explains how it was conceptualised in the study. After outlining the methodology employed, the paper explores the extent to which parental participation in family literacy provision changes family literacy practices, behaviours and attitudes, beliefs and understandings, and sheds light on how parents attending these programmes translate and actualise these messages into the home setting.

\section{Conceptions of family literacy}

There are many conceptions of family literacy that have evolved since Taylor 
(1983) first used the phrase in the 1980s when carrying out research in the US. Hannon (2003) differentiates between identifying literacy practices in the home, which is linked theoretically to a sociocultural approach, and the provision of formal programmes by schools, or other educational institutions, where parents are involved in their children's learning. According to Camilleri et al. (2005), these programmes can be further broadly divided into those aimed at improving children's literacy skills with focused parental support, and those that follow, in Hannon's term, the 'cycle of literacy' model, which set out to enhance literacy levels of both parents and children. The majority of programmes running in England today are found in school settings, and generally involve young children aged four to seven and their parents. In this study, the programmes followed the first school model: one of their main aims was to show the parents the methods used to teach literacies in school so they could use similar strategies, and offer more consistent support, to their children in the home setting. Because of the underlying premise that families, particularly those from with low social and economic status, are deficient in literacy practices and parenting skills to effectively support their child's learning, critics have accused these programmes of using a deficit model (e.g., Auerbach, 1995, 2001; Whitehouse \& Colvin, 2001). What we do know is that Research (e.g. Anderson et al., 2010; Brooks et al., 1996; Hannon et al., 2006; St. Clair, 2010; Swain et al., 2009) shows that the vast majority of parents are very positive about their experience of family literacy.

Over ten years ago Nutbrown et al. (2005) found that children showed greater progress in literacy when parents attended programmes that taught specific 
methods for improving literacy, and encouraged parents to overtly teach their pre-school children about letters and words (Sénéchal, 2006). Although these studies looked at the pre-school period, Melhuish et al. (2008) cite a number of other studies that have found similar relationships between parents attending family learning (including literacy) provision and the academic attainment of their primary school-age children (e.g. DeGarmo, et al., 1999).

\section{The home literacy environment}

We need to point out that although we use the term 'home literacy environment' in this paper, much of the literature conflates this with the "home learning environment', and when we quote from studies that use this latter descriptor we use the abbreviation 'HLE'.

The literature suggests that the home setting plays a central role, not only in the overall cognitive and socio-behavioural development of children (Melhuish et al., 2001; Harris and Goodall, 2007; Sylva et al., 2004), but also in the process of emergent literacy skills amongst preschool children (Bus et al., 1995; Hamilton, 2013; Purcell-Gates, 1996; Scarborough and Dobrich, 1994; Strickland and Taylor, 1989; Weigel et al., 2006), and children's overall literacy acquisition (e.g. Cole, 2011; Desforges and Abouchaar, 2003; Gest et al., 2004; Gutman and Feinstein, 2007; Hunt et al., 2011; McElvany and Artelt, 2009; Melhuish et al., 2008). Moreover, research such as the Effective Provision of Pre-School Education (EPPE) study (Sylva et al., 2004) also shows that children's early 
experiences of literacy in their homes are highly predictive of their attainment in school.

Although many researchers have posited that the best predictor of children's academic attainment in the early years is the level of maternal education (Mercy and Steelman, 1982; Sammons et al, 2004), Melhuish et al. (2008) maintain that this may only explain about five percent of academic achievement, and that other factors related to socio-economic status (SES) and home learning resources and activities have a significant explanatory role. Indeed, using data from the EPPE study, Melhuish et al. argue that the HLE 'exerts a greater and independent influence on educational attainment' (2008, p. 106). EPPE also adds to the hypothesis advanced by Mason and Allen (1986) and Zellman and Waterman (1998) which suggest that, although family characteristics such as SES and ethnic background have been shown to be correlated with literacy practices in the home, it is the quality of a child's relationships and learning experiences in the family that constitutes the most crucial element in improving literacy attainment. As Sylva et al. (2004) maintain, 'what parents do is more important than who parents are' (Sylva et al., 2004, p. 1).

Similarly, up until recently there has been a general tendency to assume that the great majority of children from low-income or ethnic minority families came from homes that were 'literacy impoverished' (Auerbach, 2001, p. 385, and this supposed lack of literacy experience was seen as one of the most important factors in the relationship between low SES and ethnic minority children's poor success rates at school. However, van Steensel (2006) argues that many of these conclusions were based on large-scale, quantitative studies, which made use of a 
limited conception of the home literacy environment, and the posited relationships have been called into question as a result of a series of qualitative enquiries (e.g. Auerbach, 2001; Delgado-Gaitan, 1987; Goldenberg, 2004; Purcell-Gates, 1996). Goldenberg argues that well-thought-out measures of the home literacy environment are likely to be more accurate predictors of children's literacy attainment than such factors as ethnicity and SES.

The conceptualisation and operationalisation of the home literacy environment

Research has demonstrated that the home literacy environment is not a simple construct but is multifaceted, encompassing a range of practices, attitudes and beliefs, which operate at multiple levels on development, and that different components of that environment can influence different developmental and educational outcomes (Hamilton, 2013; Weigel et al., 2006a, 2006b). Hamilton also reminds us that outcomes will also depend on the 'cognitive and motivational characteristics of the child' (2013, p. 64). In order to conceptualise the home literacy environment we used a series of measures that draw on the work of Burgess et al. (2002), van Steensel (2006), Weigel et al. (2005, 2006a, 2006b, 2010) and Wood (2002), who were the first researchers to move towards a more specific categorisation of the home literacy environment.

We categorised the home literacy environment into four dimensions, which in this paper we also use to organise and present our main findings.

i Family Resources 


\section{ii. Parental Literacy Behaviours and Attitudes}

\section{iii. Parental Beliefs and Understandings}

iv. Family Literacy Activities and Practices.

Although our categorisations are similar to those of Weigel et al. (2005) and the work of van Steensel (2006), our measurements also includes additional activities that are frequently taught on family literacy courses and which, we believe, are particularly common in, and valued by, schools: namely, shared reading, help with spellings and awareness of phonics [2]. We also added 'understandings' to the category of parental beliefs, and listed many more activities and practices in our questionnaires.

Readers will see below that we include books as part of resources. We drew on models of scholarly culture (e.g. Crook, 1997; Evans et al., 2010; Goldthorpe, 2007 [3], which also view books as material resources, and posit that the number of books in the homes indicates a family's commitment to investing in knowledge (Crook 1997; Dronkers, 1992). Books also have the potential to contribute to way of life that encourages children to read for pleasure and promote discussion, thereby increasing vocabulary, critical awareness and imagination (Bus, 2001; Bus et al.1995; Persson, 2012; Price, 2012). Thus, as Evans et al. argue, books both constitute a resource in themselves, and indicate the likely presence, or development, of other resources related to cultural capital (Bourdieu, 1997,), whereby parents gain a familiarity of the dominant, 'educated' language.

Family Resources included (i) the ages of the parent and child; (ii) the number of 
children aged under 18 years living in the family home; (iii) the sex of the child and parent; (iv) the main language the parent spoke with their child, (vi) the parent's highest educational qualification; (vii) whether the parent had attended another family literacy programme; (viii) the number of books and (ix) and the number of children's books in the family home; $(\mathrm{x})$ the parent's socioeconomic status (SES) (eligibility for Free School Meals [FSM] is used as a proxy for this).

Parental Literacy Behaviours and Attitudes referred to (i) the frequency that the parent read various materials (books, magazines etc), including digital texts; (ii) personal attitudes to reading for self; (iii) parental attitudes on the importance of reading with their child.

Parental Beliefs and Understandings included (i) how the parent rated the importance of school homework; (ii) their level of confidence in helping their child with homework; (iii) their level of understanding of how reading is taught in school; (iv) knowledge about phonics; and (v) who the parent thought had the greater responsibility for educating their child in literacy (reading, spelling, writing) - the parent or the school.

Family Literacy Activities and Practices concerned (i) the frequency with which parents or other members of the family (e.g. siblings) read with the child and (ii) helped the child with literacy school homework; (iii) the usual time of each reading session (e.g. before bedtime); (iv) frequencies of a series of specific interactions with the text while reading, such as asking questions or re-telling the story; and (v) the frequency of parents spending time with their children on a range of other, more specific, literacy-related activities and practices other 
than reading, including singing songs together, helping with spelling, writing, listening to audio books and borrowing library books.

\section{Methodology}

The research was funded by the Nuffield Foundation, and carried out by the former National Research and Development Centre for Adult Literacy and Numeracy (NRDC) at UCL Institute of Education (Swain et al., 2015). The study used mixed methods and combined a quantitative quasi-experimental design, collecting quantitative data from parental and tutor questionnaires, and qualitative data from observations of classes and in-depth parental interviews at the beginning and end of the course.

Data on the home literacy environment are based on self-report evidence from parents participating in the programmes only, and so are not drawn in comparison to a control group, and do not provide sufficient evidence for any causal statements. However, although the design does not allow us to compare any changes in the home literacy environment with the families who did not attend a programme, it still enables us to assess the relationships between the programmes and any changes in literacy practices at home. It also allows us to explore how parents used family literacy activities, translated messages and realised strategies taught in sessions with tutors since both quantitative and qualitative data were collected from the same parents at the beginning and end of the programme. 
The fieldwork took place over four school terms between September 2013 and December 2014. The final sample consisted of 27 family literacy courses for Year 1 and Year 2 pupils (aged between 5 and 7 years-old) and their parents, running in 18 Local Authorities in England. On average, these courses ran for 30 hours and enrolled nine parents and their children.

\section{Quantitative data}

Out of the 230 parents who participated in the family literacy programmes, 202 completed questionnaires at Time 1 (near the beginning of the course) and 134 at Time 2 (towards the end of the course). The attrition (34\%) between the two time points is explained by parents withdrawing from the courses (for unknown reasons), rather than because they refused to participate in the second wave of research.

Overall, for the longitudinal analysis, we had valid data from 118 parents who answered questions at both time points and we could therefore match their responses. The lower number of parents with valid data at both time points is mainly because a number of parents joined after the first session and were therefore absent for the Time 1 questionnaire.

Questionnaires for parents covered all four dimensions of the home literacy environment that we explained earlier and consisted mainly of closed questions, with a mixture of single and multiple choice questions and also some Likert-type scales. The questionnaires were distributed by family literacy tutors and took around 10-20 minutes to complete. Questions at Time 1 were devised to allow 
researchers to be able to categorise the home literacy environment and included questions about demographics, motivations to join the course and attitudes towards, and practices of, family literacy. The questions at Time 2 were designed to analyse changes in these attitudes and literacy practices, and most of the questions were a repeat of those from Time 1.

For the analysis of quantitative data we used descriptive statistics and one-group t-tests and ANOVA. All data were processed using SPSS software.

\section{Qualitative data}

A subset of 37 parents who participated in the programmes volunteered to be interviewed at the beginning and end of the course between October 2013 and December 2014. In total, 24 parents were interviewed by telephone from 17 of the 27 courses at both Time 1 and Time 2 (a total of 48 interviews). Interviews were semi-structured and typically lasted around 10 minutes at Time 1 and 15 minutes at Time 2. All conversations were audio recorded.

The themes that were pursued included parents' overall evaluation of the course and to find out if, and how, they were using the activities (such as language games) taught in the family literacy class at home. Further questions were designed to assess changes and developments in their own, and their child's attitudes towards practices in literacy, their understanding of how the school was teaching reading and writing, and their ability to support their child in literacy. Some themes that had emerged from the earlier conversations at Time 1 were developed and pursued in the second round of interviews, at Time 2.

Visits were also made to nine courses, where researchers mainly saw adult and 
joint sessions lasting, on average, around 2-3 hours per visit. Only two discrete children sessions were observed, lasting around 30 minutes each. A descriptive narrative was written with the key foci being pedagogical approaches, teacherlearner relations, activities and resources, and the learners' engagement. In addition, there were many informal conversations with tutors, parents and children, which also generated valuable data.

The qualitative analysis involved drawing out themes from each transcript using a system of 'thematic coding' (Miles and Huberman, 1994). A hybrid approach of deductive and inductive reasoning was used, and while some codes were a priori, and came from the research and interview questions, others were a posteriori codes that emerged through the analysis of the date collected. After labeling observed patterns, and sorting, comparing and contrasting data, codes were placed in a thematic and summaising matrix (Symon and Cassell, 1998). Finally, a priori and a posteriori codes were collapsed into more manageable family codes. Data were also compared, or triangulated, from interviews and observations to ensure a greater degree of trustworthiness.

\section{Findings and Discussion}

This section presents the main findings, which are organised around the four dimensions of the home literacy environment set out earlier: namely family resources, parental literacy behaviours and attitudes, beliefs and understandings and literacy activities and practices. We provide some descriptive findings that come from Time 1 survey and interviews and also outline the changes that 
occurred in these areas.

The great majority of the adult participants (95\%) were female: $93 \%$ of the participants who completed questionnaires at the beginning of the course came from female parents, almost all of them mothers. This is in line with evidence from previous research (e.g. Brooks et al., 2008; Hannon et al., 2006; Morgan et al., 2010; Rose and Atkin, 2007; Swain et al., 2009; Swain et al., 2014). Just over three-quarters of the parents were under 40 (77\% being aged between 26 and 40), and just under one fifth (19\%) were aged between 41 and 50.

\section{Dimension 1 of the home literacy environment: Family Resources}

The two socio-demographic characteristics of parents that are typically mentioned as being important in the family literacy literature are educational qualifications (Burgess et al., 2002; Christian et al., 1998; George et al., 2007; Wiegel et al., 2005) and the main language spoken at home (van Steensel et al., 2006).

Sixteen percent of parents reported having educational qualifications at Level 1 [4] or below, and the same percentage of parents said they did not have any qualifications. The combined figure of $32 \%$ is only slightly higher than the percentage of the whole population in the UK; census data reveal that $26 \%$ of the population aged between 25 and 50 possess qualifications at Level 1 or have no qualification. Two-fifths of parents (39\%) had qualifications at Level 3 or above, including 15\% who had achieved Level 6 (the equivalent of Bachelor's degree), or above, which suggests that the family literacy provision did not 
disproportionally involve disadvantaged parents with low qualifications [5]. In keeping with this educational profile, there were relatively high levels of book ownership: over two-thirds (67\%) of parents reported that they had more than 25 books (excluding children's books) in their home, while for almost a quarter of parents (23\%) this was not the first family literacy course they had attended. Almost two-thirds (62\%) spoke either mainly, or only, English at home and the most common other home languages were Urdu (13\%), Punjabi (6\%) and Bengali (5\%).

\section{Dimension 2 of the home literacy environment: Parental Literacy,}

\section{Behaviours and Attitudes}

As a part of our analysis of the home literacy environment we looked at parents' own literacy behaviours and attitudes. Most read digital texts on their mobile phones, computers, e-readers or tablets everyday (68\%), or at least once a week (18\%). Over half of parents who attended courses also read books every day (51\%), or at least once a week (27\%). Furthermore, over a quarter (26\%) of parents reported reading newspapers every day, and $40 \%$ reading them at least once a week. The least frequently read materials were magazines.

Figure 1 shows that most parents agreed that reading is an important activity in their home (91\%), and even more so when it came to reading with their children (97\%). Over three-quarters (77\%) of parents reported that they liked to spend time reading, and the same percentage talked about the books they read with other people. 
Figure 1 goes here

A paired-sample t-test was conducted to compare parents' reading attitudes and behaviours before and after attending the course. Although we found that parents experienced a change in their attitudes towards literacy after the course (Time 1: $M=15.8, S D=3.4$; Time 2: $M=16.4, S D=3.2, t(117)=-2.46, p=0.015$ ), the combined scores of reading frequency across all types of materials were not significantly higher after the courses had finished (Time 1: $\mathrm{M}=7.5, \mathrm{SD}=2.3$; Time 2: $\mathrm{M}=7.8, \mathrm{SD}=1.8, \mathrm{t}(117)=-1.57, \mathrm{p}=0.119)$. This is in line with existing research, which shows that behaviours typically take longer to change than attitudes (Reder, 2013; Reder and Bynner, 2008).

It is notable that the greatest positive change in reading behaviours was experienced by parents who had relatively few books in their households $(\mathrm{F}(4,113)=5.2, \mathrm{p}<0.001)$, and those who had a relatively large number of books recorded only minor, if any, changes in their literacy behaviours. However, these two groups had differences in baseline scores before the courses: those who had more books in their homes had higher scores, and therefore had less room for upward change. 


\section{Dimension 3 of the home literacy environment: Parental Beliefs and}

\section{Understandings}

Although most parents believed that the responsibility for general literacy development is shared between school and themselves, there were some differences between the writing, reading and spelling dimensions. While, in general terms, most parents agreed that the responsibility for these three elements can be divided equally between school and parent, more parents thought that schools should have greater responsibility for writing (14\%) and spelling (13\%), whilst only $7 \%$ of parents reported the same about reading, which was seen as being a much more equal partnership.

Evidence from the interviews suggests that the English or literacy component of homework generally involves reading and spellings activities, which are clearly

prioritised by schools. Ninety-eight percent of parents surveyed believed reading and writing homework are important for their child's learning, and almost all the parents who were interviewed accepted homework as part of the normal school routine, and saw it as a way of helping their child's education and improving achievement.

Although almost all the parents believed that homework is essential for their child's literacy development, a smaller number had enough understanding and confidence to help their children with it in the home environment. Many parents said that their main motivation for joining the programme was to understand how school literacies were taught so they could support their child more 
effectively at home. As these data demonstrate, $82 \%$ of parents wanted to learn how to help their child with their homework, and 79\% expected, and wanted, to learn how the school was teaching their child to read and write. Finally, 68\% wanted to increase their own confidence in helping their child with schoolwork. Other reasons, reported by fewer than half of the parents in the sample, were more closely related to parental development and progression: $45 \%$ wanted to increase confidence in their own literacy skills, 32\% reported that they wanted to improve their own reading, and 30\% their writing skills.

Table 1 goes here

At the beginning of the course, nearly two-thirds (63\%) of parents believed that they understood at least 'a bit' about how reading is taught at school, and just over a quarter (28\%) felt they understood 'a lot'. These figures are similar to when parents were asked how much they knew about the role of phonics in the reading process (59\% saying they understood 'a bit' and 31\% 'a lot'). Only about $10 \%$ of parents reported understanding nothing about reading or phonics. 
Questionnaire data suggest that those parents who had attended a family literacy course before thought that they had better knowledge of how reading is taught at school (including knowledge of phonics) at the beginning of their current course. Forty-one percent of those who had previously attended a programme, against $23 \%$ who had not, stated that they knew 'a lot' about how reading is taught at school. Similarly, $59 \%$ of parents who had experienced family literacy provision, compared to $22 \%$ who had not, reported that they knew a lot about how phonics is used in teaching children to read. This suggests that many of the messages and understandings from family literacy are enduring and have an ongoing effect.

Survey data show that parents reported an increase in their understanding of reading and the role of phonics at the end of the course: just over a third (35\%) moved from knowing only 'a bit' about the teaching of reading, and using phonics in the reading process, to knowing 'a lot'.

Half of the parents interviewed also stated that after only a few weeks of attending the course they were already beginning to gain a much better understanding of how the school teaches literacy in general, as is illustrated in the extracts from three different parents below:

Sometimes it's just the small things that make such a difference. It is early days really, but the things that [the tutor] spoke about, really just how the kids are being 
taught in school, and just to be able to carry that on so I'm not confusing Marion [6] [her daughter] even more

Because I now know these tricks that the teachers are using [...] I can reinforce them in the house, so it means that it's continued education

I think as parents we want to know that we are getting it right at home [...] if we don't know properly how it's being taught in school, or what they've covered, this is where I find it a little bit confusing.

These quotations show that many parents were aware that learning takes place outside the classroom. They wanted to back up the literacy teaching at school in the home context, and by being able to translate and implement the messages they had learned on the course they were, in effect, surrogate teachers. They also thought that it was important to understand, and be able to employ, the same methods and vocabulary used at school in order to minimise confusion and misunderstanding, which can lead to closer parent school relations. In a review of 1,008 studies linking parents' aspirations, attitudes and behaviours to educational outcomes, See and Gorard (2015) identified two processes, both of which can be seen in operation in the data above: namely, parent as teacher and parent-school alignment. See and Gorard argue that these may have a causal 
effect on parents' attitudes and behaviours, which in turn result in higher levels of attainment for their child/children.

The following quote also demonstrates how this understanding of school processes was leading not only to a more consistent approach to the development of literacy in both home and school contexts, but also to more relaxed and positive parent-child relationships.

Parent: $\quad$ I have a lot of trouble with my daughter, she's only five, and all hell breaks loose when we are trying to do reading, writing, spelling at home, and we both end up... it's been tears and fighting and screaming, you know, and mainly I didn't, like at the minute she's just kind of, now I'm understanding what phonics is and how it's taught in school, and how Maxine's [the child] actually taught it, they give me like little hints and tips, like games that help with the phonics, and your reading and your writing, so trying to make it more fun so it's not so stressful, because it's an awful thing because you are always trying to do the best, but then you get to a point where, you know, if you are going to end up arguing all the time you get to dread it.

By the end of their course, half of the 24 parents interviewed reported that they had a 'much better' or 'deeper' understanding and greater appreciation of how 
school literacies are taught, while nine thought that their understanding had increased 'quite a lot'. Likewise, 94\% of parents who completed questionnaires stated that the course helped them to understand how their child was being taught the curriculum in general at school, although from the survey we do not know how much their understanding changed, and in what ways. The interviews help to shed some light on these changes in the parental understanding of phonics, as already mentioned in the quotation above.

Researcher: What sort of things has it [the family literacy programme] really helped you with the way you approach reading with your children?

Parent: $\quad$ Well, I think probably like the phonics, like breaking words down, because she produced this sheet, because obviously I was never taught phonics at school, so it's like an education for the parents as well, and you don't realise the words that will make, pair of words that will make the sound, and it was an eye opener to me, obviously you know them but then you think oh yeah, I just never thought. [...] It's helpful for me as a parent because obviously it helped me sort of teach my child more at home, definitely with the phonics bit.

Both sets of data showed that by the end of the course the great majority of parents felt more able to support their child with literacy homework, with $82 \%$ of the parents surveyed saying that the course had helped them learn strategies to support their child with their homework more effectively. Questionnaire data 
also confirmed that there was an increase in parents' confidence when helping their children with their homework (Time 1: $M=2.95, S D=1.03$; Time 2: $M=3.28$, $\mathrm{SD}=0.85, \mathrm{t}(115)=-3.68, \mathrm{p}<0.001)$

\section{Dimension 4 of the home literacy environment: Family Literacy Activities and Practices}

\section{Frequencies of shared literacy activities}

Over three-quarters of parents already reported at the start of the programmes that they read with their children every day, or almost every day (76\%), with a further $19 \%$ reading with them a few times a week. About a third (35\%) stated that their partners read with their children every day or at least a few times a week. Since $95 \%$ of parents who completed the questionnaire were women, we can surmise that most of them were the main reader to their children, and that few male partners read with their children with the same frequency. It was very rare for any other family member to read with a child.

It is a similar picture with respect to helping children with the reading and writing activities sent home from schools: $68 \%$ of parents (again, almost all women) helped their children with these activities every day or almost every day, and $27 \%$ did so a few times a week. With regard to the length of reading sessions, the most frequently mentioned duration was 10 to 30 minutes per session (53\%), followed by sessions of 5-10 minutes (40\%). Qualitative data suggest the most common pattern of reading took the form of a child reading their school reading scheme book to their mother soon after returning home 
from school, and then, later, choosing their own book around, or nearer to, bedtime.

A review of the literature on early reading practices by Hamilton (2013) shows that, in general, parents appear to view shared storybook reading as an opportunity to enhance their children's comprehension and vocabulary, rather than as a context within which to teach specific decoding skills. Our data reflect this argument (see Figure 2): when asked about actual shared reading practices, about half of parents surveyed reported (i) asking their child questions about the book or text (52\%) and (ii) talking about the reading every time they were involved in shared reading with a child (48\%); 38\% reported (iii) re-reading parts of a favourite story or text, and 33\% said that they (iv) took turns in reading aloud, while a further $26 \%$ (v) asked their child to re-tell the story and $23 \%$ of parents (vi) retold the story themselves every time they read together. Although most parents did not perform most of the last five literacy practices (iivi) every time they read a book or text with their child, around half the parents said they used these practices, at least on some occasions.

Figure 2 goes here

The most common literacy activities 
The most commonly reported parental literacy activity was shared reading with their child (see Figure 3) and 70\% of parents testified to doing this every day. In terms of popularity, this was followed by helping their child with spellings and/or phonics, writing together, singing songs, and watching educational programmes on the TV or computer. Over half (51\%) the parents still visited a library and borrowed books at least once or twice a week, and 21\% reported visiting almost every day. Playing rhyming or other language games and listening to audio books were relatively infrequent activities.

Figure 3 goes here

We summed up these shared literacy activities to create a scale ranging from 0 to 75; the higher the value, the more often these shared activities took place (as reported by parents). On this scale, the mean value at Time 1 was 52 , with a standard deviation of 9. Based on ANOVA analysis, these data provide evidence that those parents with higher qualifications $(F(5,187)=3.19, p=0.01)$, those who had more books in general $(\mathrm{F}(4,193)=4.66, \mathrm{p}<0.001)$, and more children's books in particular $(F(4,192)=4.87, \mathrm{p}<0.001)$, and those who had attended a family literacy course before $(F(1,198)=5.51, p=0.02)$ also reported being involved in shared literacy activities with their children more often. However, we 
did not find evidence of any relationship between the main languages spoken at home and shared literacy activities.

A paired-sample t-test was conducted to compare the shared literacy activities between parent and child, at the beginning $(M=54.2, S D=6.7)$ and towards the end the course $(M=51.75, S D=8.5)$, and the scores were higher towards the end $t$ (117) $=-3.73, p<0.001$. Interestingly, however, there were no differences with regard to changes in the frequency of shared literacy activities based on educational qualifications, language spoken at home, previous attendance on family learning programmes, or the number of books in the home.

We investigated the frequency of other shared literacy activities. Some were already taking place frequently, and we found no evidence of a change. These included: reading a story together, writing, helping with spelling, phonics or singing songs together or playing educational games on computer. However, other activities did increase in frequency, including: telling stories (without a book) $(\mathrm{t}(117)=-2.18, \mathrm{p}=0.03)$, playing rhyming and other language games $(t(117)=-1.93, p=0.06)$, watching educational programmes on TV or computer $(\mathrm{t}(117)=-2.26, \mathrm{p}=0.03)$, visiting a library $(\mathrm{t}(117)=-3.20, \mathrm{p}<.001)$ and borrowing books from the library $(\mathrm{t}(117)=-3.62, \mathrm{p}<0.001)$.

We found no significant change in the frequency of shared reading or helping with homework, which might be explained by the reported high level of activity in these two areas in the early days of the programme. However, there was a slight increase in the amount of time parents spent on reading sessions ( $\mathrm{t}$ (118) $=-1.88, p=0.06$ ) by the end of the course. That could be explained by the increase in some of the specific ways parents read with their children that takes a longer 
time.

An important theme to emerge during the cycle of interviews was the change in the quality of interactions and experiences between parent and child when they engaged in the reading process together. Of the 24 parents 21 had noticed a number of changes, and in most cases these were substantive and potentially farreaching. Quantitative data also supported this finding: there were significant changes in how parents carried out shared reading activities and practices between the two time points $(\mathrm{t}(117)=-3.46, \mathrm{p}<0.001)$.

As conversations with parents after their course demonstrate, these changes included how to engage their child more deeply in literacy activities, to make the learning experience richer, more enjoyable and more meaningful, and also learning techniques and strategies for teaching elements of literacy such as spelling, punctuation and grammar. The course also provided ideas that gave opportunities to talk about and use literacy informally in the home literacy environment, and as an integrated part of everyday life within the community.

It's not all about just the reading books that they bring home from school; it's about incorporating it all. For example, the other day we had takeaway pizza, and Rebecca wanted to read everything that was on the takeaway box, and then we had a conversation about Italy, and obviously my little boy joined in, and I've got a two-yearold as well, and she tried to join in, she drew a picture of the flag and stuff. So it's just about, you know, looking for opportunities for 
literacy as well, and I think that's what you take away from the class, apart from the theory around literacy, and how children are learning their literacy, it's how you can incorporate it in everyday life, that's what parents are having conversations around.

This quotation shows that a growing number of parents were becoming aware that opportunities for developing their children's literacy were not confined to the classroom. Also that learning is often informal, opportunistic and crosscurricular, which also has benefits for other family members.

Looking at quantitative data on separate activities, we found no significant change with regard to asking questions about a book and discussing a book with a child after reading it. However, once again, the frequency of those two activities was already quite high at the beginning of the course. We found a significant increase across four of the other activities used during the shared reading process: how often parents retold the story from the book $(\mathrm{t}(117)=-2.39$, $\mathrm{p}=0.02)$, or asked their child to do it $(\mathrm{t}(117)=-2.27, \mathrm{p}=0.03)$, re-read favourite books, chapters or pages $(\mathrm{t}(117)=-1,77 \mathrm{p}=0.08)$ and took turns reading aloud $(\mathrm{t}(117)=-3.56, \mathrm{p}<0.001)$.

In interviews, parents stated that one of the most important changes they had learned from the course was to make the reading process much more interactive, and they and their children were making more of their joint engagement with the text. In contrast to the quantitative finding above, many of those stated that they now were asking far more questions about the text to assess 
comprehension, and there was a greater focus on understanding and other reading skills concerned with making connections and predictions, which provide learners with deeper meanings and gives them a greater reason to read.

You know actually you know the way, as we are doing before, writing and reading, it was different, we'd read and we'd keep in mind so many things, and when I am reading a story I now ask my child what will happen next, and he says something. Before that I wasn't asking him any questions. So many questions I now ask, what will happen there, what will happen next, and what have you concluded when you have read the story? What was that connected to and what he was doing and things like that?

It may be that different findings can emerge when the questions asked are accompanied with a greater contextual explanation, and that this can result in a series of deeper insights that the quantitative methods are sometimes not always able to capture.

A further significant change to emerge was that the reading experience had become more pleasurable for both parent and child. Reading for pleasure is critical for ensuring that the practice needed to become fluent becomes part of the learners' everyday life, and young children are more likely to want to pick up another book and read more if they enjoy the experience (DeBaryshe et al., 2000; Sonnenschein et al., 2000; Weigel et al., 2006b). Data from our study show that for a growing number of families reading was becoming an activity to be relished and looked forward to, rather than as just 'something to be done', or 'ticked off', and entered into the child's school reading diary. Parents felt more relaxed, more unhurried and were more patient, letting the child take greater control; they did 
not feel as if they had to correct every mispronunciation and, rather than simply tell the children whatever word they may not have known, they would first ask the child to make a prediction or have a guess. Some of these changes are illustrated in the extract below:

Parent: $\quad$ It's [still] reading but enjoying reading, not reading for the sake of reading, whereas before that's what I were doing, I were trying to get him learning to read, but because I was like no, sit down, you've got to do this, you have to do this, he just wasn't interesting and didn't do it. Whereas now he does, he enjoys it and he might say the odd word wrong and I don't point it out to him, I leave it, because again it's that telling them they are wrong again, and then they don't like it.

Researcher: So what's different now from a few months ago?

Parent: I'd say I'm a lot more relaxed. At one time it was OK, come on, get your books out, get it done type of thing, what does that letter say? And yes, I would praise, because, you know, I understand in my job all about praise, but I'd say I've a lot more time, you know, I'll set aside twenty minutes, instead of just rushing it through, five, ten minutes, or I'll put the threeand four-year-old to bed and me and Robert will have, you know, ten, fifteen minutes after, even if I'm just reading him books, following the words with my finger, and he takes turns more so he enjoys the story now, and take the emphasis off having to say what the word is, because it's all just use isn't it, 
it's however many times you've seen a word that you'll recall the word.

Some parents observed that their children were gaining in confidence and were initiating the reading interaction between them, and this may be connected to parental perceptions of their children's reading having improved over the time of the course..

\section{Conclusion}

This paper set out to present data on how participation in family literacy provision changes family literacy practices behaviours, attitudes, beliefs and understandings, and to develop knowledge on how parents translate and implement messages from their courses into the home setting. Although our study is high on internal validity, as we could triangulate the data from parental pre and post interviews and surveys, there are some limitations with regards to external validity and reliability. Firstly, the low overall numbers of parents who participated in the programmes, and attrition of parents, meant that the quantitative data were only based on 118 participants. Some parents also enrolled late, which meant that they missed the Time 1 assessment and were therefore excluded from the final dataset. Secondly, it was not possible to find longer programmes of around 70 hours, and these may have raised different issues and shown potentially greater and/or different effects. Finally, the reliability of our findings maybe limited as we had to rely on the parental selfreports from the interviews and the surveys, rather than any observational data 
of the home literacy environment.

The main contribution to the field of family literacy is the evidence presented in the paper, which confirms that the home literacy environment plays a fundamental role in the process of literacy acquisition, and the data that show that many of parents were able make changes in, and to, the home setting by being able to translate and transfer the schools' ways of teaching literacy into the home and beyond.

The critical role of parents in supporting and improving their children's literacy and language development has been well documented over the last 30 years (e.g. Anderson et al., 2010; Brooks et.al., 1996, Bus et al., 1995; Hannon, 1986; Timmons and Pelletier, 2014; Wagner et al., 2002), and family literacy provision aims to empower the parents by highlighting their vital role as co-educators. The study confirms previous research (e.g. DeGarmo et al., 1999; Melhuish et al., 2008; Nutbrown et al., 2005), and shows how family literacy courses have a particular benefit for families when they teach specific methods for improving literacy. By the end of the programmes parents had a greater understanding of school literacies and the strategies that were used in the classroom, and by replicating some of these, parents ensured that there was a more consistent and cohesive approach to teaching literacy between the two settings. We do not see this as a deficit model as this is what parents wanted, and the programmes were meeting many of their needs. In effect, the courses were training parents how to implement school-based literacies into the home setting where they were acting as surrogate teachers. This is not to suggest that parents are, or should in some 
way, be replacing the role of highly trained professionals, but that many are able, or at least have the potential, to add to, reinforce and complement what teachers do in the classroom in the context of the home setting and therefore extend literacy learning beyond formal school environment.

Parents' own attitudes towards reading showed significant improvements between the start and the end of the course, although there was no difference in their own reading behaviours, which generally take longer to change (Reder, 2013; Reder and Bynner, 2008). The research also found a significant increase in parents' confidence, which enabled them to offer better support to their child with homework, and parents also improved their understanding of how reading (including the use of phonics) is taught at school.

Overall, parents reported reading with their children every day, or almost every day, and regularly supporting children with literacy work sent home from school. A much smaller proportion used specific reading strategies or practices, such as taking turns, reading aloud or asking their child to re-tell a story at the start of the provision. Although there was no significant change in the frequency of shared reading, or in parents helping with homework after the course, data suggest that there were important changes in the quality of the interactions and type of activities in joint reading; many parents were found to be asking more questions to assess comprehension and there was a greater general focus on understanding and making predictions. A further, and potentially far-reaching, change was that the reading experience had become more relaxed, more pleasurable, and more meaningful for both parent and child. 
The main implications for policy and practice are that family literacy provision should remain integral to government educational policy. By ring fencing funding local authority managers and other providers would be able to plan ahead strategically, and it would enable them to build up and maintain key partnerships with schools over the long term. There should also be longer programmes, and a greater flexibility to be able to extend courses to around 70 hours, where parents are keen for this to happen. However, further research is needed to explore whether changes in children and parents are greater when programmes have more hours than the average 30 hours of contact time found in this study.

\section{Notes}

[1] The term 'parent(s)' is used throughout the paper to refer to mothers, fathers and carers.

[2] Phonics (including synthetic phonics that first teaches the letter sounds and then builds up to blending these sounds together to achieve full pronunciation of whole words) are now the main method that schools in the UK teach children to learn to read words (Rose, 2006), and many parents are unfamiliar with this approach from their own school days.

[3] Evans et al. (2014) used the OECD's PISA (The Programme for International 
Student Assessment) study to analyse data from 200,144 cases in 42 countries, and again concluded that there is a strong, statistically significant correlation between the number of books in the family home and children's academic performance. This was the case in every one of the 42 countries on internationally normed tests, even after controlling for other well-known factors correlated with educational performance, such as parents' levels of education, parents' occupation and family wealth.

[4] In the National Qualifications Framework (NQF), Level 1 corresponds to a level expected of a 'poor' GCSE (General Certificate of Secondary Education), Grades D-G, which is a qualification generally taken by 16-year-olds in England. Level 3 is equivalent to A Level (or the General Certificate of Education Advanced Level), which is a school-leaving qualification generally taken by 18-year-olds.

[5] It is interesting to note that only about one quarter (24\%) of parents expected or wished to gain a literacy qualification and most family literacy programmes in this study did not provide opportunities for parents to gain them. [6] All the names of the participants in this paper have been changed. 


\section{References}

Anderson J, Anderson, A, Friedrich, N. and Kim, JE (2010) Taking stock of family literacy: some contemporary perspectives. Journal of Early Childhood Literacy 10(1): 33-53.

Auerbach E (1995)Deconstructing the discourse of strengths in family literacy. Journal of Reading Behavior, 27: 643-659.

Auerbach E (2001) Towards a social contextual approach to family literacy. In: Beck SW and Nabors Olah L (eds.) Language and literacy: Beyond the here and now Cambridge MA: Harvard Educational Review, pp. 381-397.

BIS (2014) Adult Literacy and Numeracy: Government Response to the House of Commons, Business, Innovation and Skills Select Committee Fifth Report of Session 2014-15.

https://www.gov.uk/government/uploads/system/uploads/attachment data/fi le/395301/bis-15-48-government-response-to-the-bis-committee-fifth-reportof-session-2014-to-2015-on-adult-literacy-and-numeracy-Cm-8982-printversion.pdf (accessed 8 January 2017)

Bourdieu P (1997) The Forms of capital. In: Halsey AH, Lauder H, Brown P and Stuart-Wells A (eds) Education: Culture, economy and society. New York: Oxford University Press, pp. 46-58..

Brooks G, Gorman T, Harman J, Hutchison D, and Wilkin A (1996) Family literacy 
works: The NFER Evaluation of the Basic Skills Agency's Family Literacy

Demonstration Programmes. London: Basic Skills Agency.

Brooks G, Gorman, T, Harman J, Hutchison D, Kinder K, Moor H, and Wilkin A (1997) Family literacy lasts. London: Basic Skills Agency.

Brooks G, Pahl K, Pollard A and Rees F (2008) Effective and inclusive practices in family literacy, language and numeracy: a review of programmes and practice in the UK and internationally. England: CfBT

Burgess SR, Hecht SA and Lonigan CJ (2002) Relations of the home literacy environment (HLE) to the development of reading-related abilities: A one-year longitudinal study. Reading Research Quarterly 37: 408-426.

Bus AG, van Ljzendoorn MH and Pellegrini AD (1995) Joint book reading makes for success in learning to read: A meta-analysis on intergenerational transmission of literacy. Review of Educational Research 65: 1-21.

Bus, A. G. (2001) Joint caregiver-child storybook reading: A route to literacy development. In: Neuman SB and Dickinson DK (eds.) Handbook of early literacy research. New York: Guilford Press, pp. 179-191.

Camilleri, J., Spiteri S. and Wofendale, S. (2005) Parent empowerment for family literacy: a European initiative. Parent empowerment for family literacy, 39, (2), $74-80$.

Carpentieri JD, Fairfax-Cholmeley K, Litster J and Vorhaus J. (2011) Family literacy in Europe: using parental support initiatives to enhance early literacy development. London: NRDC, Institute of Education, University of London. 
http://ec.europa.eu/education/policy/school/doc/family-literacy en.pdf (last accessed 7 January 2015).

Christian K., Morrison FJ and Bryant FB (1998) Predicting kindergarten academic skills: Interactions among child care, maternal education, and family literacy environments. Early Childhood Research Quarterly 13: 501-521.

Cole (2011) A research review: the importance of families and the home environment. Originally written by Angelica Bonci, 2008, revised June 2010 by Emily Mottram and Emily McCoy and March 2011 by Jennifer Cole. National Literacy Trust http://www.literacytrust.org.uk/assets/0000/7901/Research reviewimportance of families and home.pdf (last accessed 7 January 2017) Crook C (1997) The Dimensionality of Stratification-Related Cultural Practices in Australia. Australian and New Zealand Journal of Sociology 33: 226-238.

DeBaryshe BD (1995) Maternal belief systems: linchpin in the home reading process. Journal of Applied Developmental Psychology 16: 1-20.

DeGarmo DS and Forgatch MS (1999) Contexts as predictors of changing parenting practices in diverse family structures: A social interactional perspective to risk and resilience. In: Hetherington EM (ed.), Coping with divorce, single parenting and remarriage: A risk and resiliency perspective. Mahwah, $\mathrm{NJ}$ : Erlbaum, pp. 227-252.

DeGarmo DS, Forgatch MS and Martinez CR (1999) Parenting of divorced 
mothers as a link between social status and boy's academic outcomes. Child Development 70: 1231-1245.

Delgado-Gaitan C (1987) Mexican adult literacy. New directions for immigrants. In: Golman SR and Trueba K (eds) Becoming literate in English as a second language Norwood, NJ: Ablex, pp. 9-32.

Desforges C and Abouchaar A (2003) The impact of parental involvement, parental support and family education on pupil achievements and adjustments: a literature review. London, DfES.

Dronkers J (1992) Parents, Love and Money. International Perspectives on Education and Society 2: 277-293. .

Evans MDR, Kelly J, Sikora J and Treiman DJ (2010) Family Scholarly Culture and Educational Success. Research in Social Stratification and Mobility 28: 171-197.

Evans MDR, Kelly J and Sikora J (2014) Scholarly Culture and Academic Performance in 42 Nations. Scholarly Test Scores. Social Forces 92(4): 15731605.

George A, Hansen K and Schoon I (2007) Cognitive Development. Millennium Cohort Study Briefing 1 June 2007: London: Centre for Longitudinal Studies.

Gest SD, Freeman NR, Domitrovich, CE and Welsh JA (2004) Shared book reading and children's language comprehension skills: the moderating role of parental discipline practices. Early Childhood Research Quarterly 19: 319-336. 
Goldenberg C (2004) Literacy for low-income children in the 21 st century. In:

Unrau N and Ruddell R(eds.) Theoretical models and the processes of reading.

Newark, DE: International Reading Association, pp. 1636-1666.

Goldthorpe J H (2007) Cultural Capital. Acta Sociologica 50: 211-229.

Gutman L and Feinstein L (2007) Parenting Behaviours and Children's

Development from Infancy to Early Childhood: Changes, Continuities, and

Contributions. Centre for Research on the Wider Benefits of Learning

Hannon P (1986) Teachers and parents' experiences of parental involvement in the teaching of reading. Cambridge Journal of Education 16(1): 28-37.

Hannon P.(2003) 'Family literacy programmes', In Hall, Larson NJ and Marsh J (eds),Handbook of Early Childhood Literacy Research. London: Sage, pp. 99-111.

Hannon P, Morgan A and Nutbrown C. (2006) Parents' experiences of a family literacy programme. Journal of Early Childhood Research 4(1): 19-44.

Hamilton J (2013) The Role of the Home Literacy Environment in the Early Literacy Development of Children at Family-risk of Dyslexia. PhD thesis, University of York

Harris A and Goodall J (2007) Engaging parents in raising achievement: do parents know they matter? London: DCSF. Retrieved 30 July 2008 from www.dcsf.gov.uk/research/data/uploadfiles/DCSF-RW004.pdf Accessed 10 August 2016. 
Hirst K (1998) Pre-school literacy experiences of children in Punjabi, Urdu and Gujerati speaking families in England. British Educational Research Journal 24 (4): 415-429.

Hodge R (2006) Effective practices in family literacy, language and numeracy project: Report of Phase 2 Case Study: Inspiration and aspiration: exploring the nature and success of FLLN provision in a multilingual context. Lancaster Literacy Research Centre: NRDC/CfBT Trust.

Hunt S, Virgo S, Klett-Davies AP and Apps J (2011) Provider Influence on the Home Learning Environment. Department for Education. Research Report DFERR142

http://dera.ioe.ac.uk/3998/1/3998_DFE-RR142.pdf (last accessed 7 January 2017)

Mason J and Allen JB (1986) A review of emergent literacy with implications for research and practice in reading. Review of Research in Education 13: 3-47.

McElvany N and Artelt C (2009) Systematic reading training in the family: Development implementation, and initial evaluation of the Berlin Parent-Child Reading Program. Learning and Instruction 19: 79-95.

Melhuish E. Sylva, C, Sammons P, Siraj-Blatchford I and Taggart B (2001) Social, behavioural and cognitive development at 3-4 years in relation to family background. The effective provision of pre-school education, EPPE project. DfEE: London: The Institute of Education.

Melhuish E, Phan Mai B, Sylva K, Sammons P, Siraj-Blatchford, I and Taggart B (2008) Effects of the home learning environment and preschool center 
experience upon literacy and numeracy development in early primary school. Journal of Social Issues 64: 95-114.

Mercy JA and Steelman L C (1982) Familial influence on the intellectual attainment of children. American Sociological Review 47: 532-542.

Miles M and Huberman M (1994) Qualitative Data Analysis: An expanded Sourcebook. London: Sage.

Morgan PL, Frisko ML, Farkas G and Hibel J (2010) A Propensity Score Matching Analysis of the Effects of Special Education Services. Journal of Special Education 43(4): $236-254$

National Adult Literacy Agency (NALA) (2010) At home with literacy: a study of family literacy practices. Dublin, Ireland: The National Adult Literacy Agency.

National Institute for Adult and Continuing Education (NIACE) (2013) Family Learning Works: an inquiry into Family Learning in England and Wales. Leicester: NIACE.

Nichols S, Nixon H and Rowsell J (2009) The "Good" Parent in Relation to Early Childhood Literacy: Symbolic Terrain and Lived Practice. Literacy: Special Issue on Identity $43(2): 65-74$.

Nutbrown C, Hannon P and Morgan A (2005) Early literacy work with families: policy, practice and research. London: Sage.

Persson M (2012) Does type of education affect political participation? Scandinavian Political Studies 35(3): 198-221. 
Price . (2012) How to do things with books in Victorian Britain. Princeton, NJ:

Princeton University Press.

Purcell-Gates V (1996) Stories, coupons and the TV Guide: Relationships between home literacy experiences and emergent literacy knowledge. Reading Research Quarterly, 31: 401-238.

Reder J and Bynner J (2008) Tracking Adult Literacy and Numeracy Skills:

Findings from Longitudinal Research. London: Routledge Research in Education.

Reder S (2013). Lifelong and life-wide adult literacy development. Perspectives on Language and Literacy 39(2): 18-22.

Rose J (2006) The Independent Review of the Teaching of Early Reading. London: Department for Education and Skills (DfES).

Rose A and Atkin C (2007) Family literacy in Europe: Separate agendas? Compare 37(5): 601-615.

St. Clair R (2008) Reading, writing, and relationships: human and social capital in family literacy programs. Adult Basic Education and Literacy Journal 2(2): 84-93.

Scarborough HS and Dobrich W (1994) On the efficacy of reading to preschoolers. Developmental Review 14: 245-302.

See B H and Gorard S (2015) The role of parents in young people's education - a critical review of the causal evidence. Oxford Review of Education. Published online. http://dro.dur.ac.uk/15024/ (last accessed 8 January 2017) 
Sénéchal M (2006) Testing the home literacy model: parent involvement in kindergarten is differentially related to Grade 4 reading comprehension, fluency, spelling, and reading for pleasure. Scientific Studies of Reading 10(1): 59-87.

Sonnenschein S, Baker L, Serpell R and Schmidt D (2000) Reading is a source of entertainment: the importance of the home perspective for children's literacy development. In: Roskos KA and Christie JF (eds) Play and literacy in early childhood: research from multiple perspectives. Mahwah, NJ: Lawrence Erlbaum, pp. 107-124.

Strickland DS and Taylor D (1989) Family storybook reading: implications for children, families, and curriculum. In: Strickland DS and Morrow L(eds) Emerging literacy: young children learn to read and write. Newark DE: International Reading Association, pp. 147-159.

Swain J, Brooks G and Bosley S (2014) The benefits of family literacy provision for parents in England. Journal of Early Childhood Research 12(1): 77-91.

Swain J, Welby S, Brooks G, Bosley S, Frumkin L, Fairfax-Cholmeley K, Pérez A and Cara 0 (2009) Learning literacy together: the impact and effectiveness of family literacy on parents, children, families and schools. Executive summary October. Coventry: Learning and Skills Improvement Service. http://www.nrdc.org.uk/publications_details.asp?ID=162 Last accessed 7 November 2017.

Swain J, Cara O, Vorhaus J and Litster J (2015) The impact of family literacy programmes on children's literacy skills and the home literacy environment. Research Report. National Research and Development Centre for adult literacy 
and numeracy (NRDC). UCL, Institute of Education, University College London. http://www.nuffieldfoundation.org/sites/default/files/files/Nuffield-FamilyLiteracy-Report.pdf. Last accessed 7 November 2017.

Sylva K, Melhuish E, Sammons P Siraj-Blatchford I and Taggart B. (2004) The Effective Provision of Pre-School Education (EPPE) Project: Final Report. A Longitudinal Study Funded by the DfES 1997-2004. London: Department for Education and Skills/Institute of Education, University of London Symon G and Cassell C (eds) (1998) Qualitative Methods and Analysis in Organisational Research: A Practical Guide. London: Sage.

Taylor D (1983) Family Literacy: Young Children Learning to Read and Write. Exeter, NH: Heinemann.

Taylor D (ed) (1997) Many Families, Many Literacies an International Declaration of Principles. Portsmouth (US): Heinemann.

Timmons K and Pelletier J (2014) Understanding the importance of parent learning in a school-based family literacy programme. Journal of Early Childhood Literacy 14(3): 1-23.

van Steensel R (2006) Relations between socio-cultural factors, the home literacy environment and children's literacy development in the first years of primary education. Journal of Research in Reading. 29(4): 367-382.

van Steensel R, McElvany N, Kurvers J and Herppich S (2011) How Effective Are Family Literacy Programs? Results of a Meta-Analysis. Review of Educational Research 81(1): 69-96. 
Wagner M, Spiker D and Linn M (2002) The effectiveness of the Parents as Teachers program with low- income parents and children. Topics in Early Childhood Special Education 22(2): 67-81.

Weigel DJ and Martin S. (2005) Ecological influences of the home and child-care center on preschool-age children's literacy development. Reading Research Quarterly 40(2): 204-233.

Weigel DJ and Martin S and Bennett K (2006a) Contributions of the home literacy environment to preschool-aged children's emerging literacy and language skills. Early Child Development and Care 176(3 \& 4): 357-378.

Weigel DJ and Martin S and Bennett K (2006b) Mothers' literacy beliefs: connections with the home literacy environment and pre-school children's literacy development. Journal of Early Childhood Literacy 6(2): 191-211.

Weigel DJ and Martin S and Bennett K (2010) Pathways to literacy: connections between family assets and preschool children's emergent literacy skills. Journal of Early Childhood Research 8(1): 5-22.

Whitehouse M. and Colvin C (2001) “Reading” families: Deficit discourse and family literacy. Theory into Practice 40: 212-219.

Wood C (2002) Parent-child pre-school activities can affect the development of literacy skills. Journal of Research in Reading 25(3): 241-258.

Zellman GL and Watermann JM (1998) Understanding the impact of parent 
school involvement on children's educational outcomes. The Journal of Educational Research 91: 370-380. 